\title{
A sociologia católica de Alceu Amoroso Lima con- tra a sociologia durkheimiana no Brasil ${ }^{1}$
}

\author{
Juarez Lopes de Carvalho Filho* \\ https://orcid.org/0000-0002-3508-4959
}

Introdução: situando o problema

O embate entre a sociologia durkheimiana e a sociologia católica vem desde os tempos da fundação da sociologia como ciência. A sociologia desde a época de Durkheim assiste, na França e em outros países da Europa (Bélgica, Itália), ao retorno da filosofia tomista, resultado de uma "estranha aliança" entre a Igreja católica e os intelectuais (Serry, 2004b). Esse projeto buscava impedir o avanço da sociologia acadêmica durkheimiana e estabelecer o catolicismo social, permitindo à instituição católica recuperar seu prestígio na sociedade moderna. Essa "sociologia católica" encontra seus fundamentos no tomismo e no ensino social da Igreja. $\mathrm{O}$ retorno ao tomismo se manifesta sob a influência da Encíclica Aeterni Patris (1879), na qual Leão XIII recomendava incorporar à doutrina de Tomás de Aquino os resultados das pesquisas científicas contemporâneas. Lançadas as bases do pensamento da filosofia cristã, Leão XIII lança a Encíclica Rerum Novarum (1891), texto fundador do catolicismo social.

1. O presente artigo é parte do resultado de uma pesquisa no âmbito de um pós-doutorado realizado na Université de Lorraine, sob a supervisão de Lionel Jacquot, no ano universitário 2016-2017, cujo título foi La sociologie durkheimienne face au néo-thomisme français: pour une étude comparative entre la France et le Brésil. A pesquisa foi financiada pela Fapema (Fundação de Amparo à Pesquisa e ao Desenvolvimento Científico e Tecnológico do Estado do Maranhão). 
Para entender em que condições isso foi possível, foi necessário identificar os agentes sociais e os órgãos qualificados, que, como na França, contribuíram para a profissionalização do ensino em Filosofia e Sociologia. Como na França, a Igreja no Brasil recrutou seus porta-vozes nos círculos intelectuais habilitados por uma mobilização de capital econômico, social e cultural, alinhada à tradição da filosofia espiritualista de Bergson e ao neotomismo de Jacques Maritain, que marcou profundamente o pensamento social católico brasileiro. Esta pesquisa mostrou que, apesar de a sociologia durkheimiana ter sido difundida tardiamente no Brasil, no final dos anos $1930^{2}$, em comparação com o que se passou na França, os elementos são bastante similares. Paralelamente ao estabelecimento de instituições de ensino superior de educação no campo das ciências humanas e sociais, a Instituição católica é responsável pela criação de dispositivos institucionais, que são armas de resistência para preservar e recuperar sua legitimidade no mundo social, em declínio desde a instalação dos valores republicanos e democráticos. Em um caso e no outro, o que observamos são les enjeux sociaux de luta e concorrência para dizer a "verdade" sobre o mundo social (objeto por definição da sociologia), cuja construção não é de modo algum o produto da natureza ou da vontade divina, mas uma construção de processos sociais historicamente situados.

De cunho histórico, bibliográfico e documental, este trabalho se inscreve numa sociologia dos intelectuais, consagrando um lugar especial a Alceu Amoroso Lima (1893-1983), figura central no corpus da tradição intelectual católica brasileira. A pesquisa concluiu que Amoroso Lima se alinha aos católicos sociais franceses por sua origem social, sua trajetória no espaço acadêmico, que combina fracassos universitários e reconversão do capital social e simbólico; e sua inscrição no campo filosófico ligado ao espiritualismo bergsoniano no início e, mais tarde, ao neotomismo de Maritain são prerrogativas que lhe dão direito de entrar no campo das ciências sociais, cujo projeto era fundar uma sociologia católica no Brasil embasada nos mesmos princípios do catolicismo social e dos valores neotomistas e cristãos.

Em primeiro lugar, para situar o caso no Brasil, foi importante compreender as estratégias da instituição católica em países como a França e a Bélgica, importantes para instituir uma corrente sociológica chamada de católica ou cristã, capaz de con-

2. Cabe lembrar que, embora a obra de Durkheim tenha sido comentada no final do século xıx por Paulo Egydio de Oliveira Carvalho no seu livro Estudo de sociologia criminal. Do conceito geral do crime segundo o método contemporâneo: a propósito da teoria de Durkheim (1900), é somente em 1935, com a publicação de Princípios de sociologia de Fernando de Azevedo, cuja arquitetura retoma com grande fidelidade As regras do método sociológico de Durkheim, que a sociologia deste começa a ser difundida entre nós. Em 1937, sob os auspícios do mesmo Fernando de Azevedo, será publicado o livro As regras do método sociológico. Em 1939, será a vez de Educação e Sociologia. Cf. Oliveira (2009, pp. 231-257). 
correr com a sociologia científica e acadêmica, em especial a sociologia durkheimiana. Ressaltam-se nesse contexto os diferentes dispositivos (institutos católicos e manuais de sociologia), importantes na difusão da sociologia católica fundada na doutrina social. Nesse momento, procuramos verificar os mecanismos da difusão do neotomismo francês no meio intelectual católico brasileiro.

Em um segundo momento, evocamos figuras mais representativas do neotomismo no Brasil, a fim de identificar as agências e agentes da difusão do neotomismo francês no Brasil. Em seguida, trazemos elementos da trajetória social e intelectual de Alceu Amoroso Lima. E, por fim, apresentamos alguns postulados da sociologia católica de Amoroso Lima expostos no livro Preparação à Sociologia, de importante difusão no Brasil, no qual se pode verificar a oposição feita à sociologia durkheimiana.

O neotomismo contra a sociologia durkheimiana na França: estratégias católicas de refundação do neotomismo

A sociologia durkheimiana foi alvo de várias contestações, seja no campo filosófico, em que ela se inscreve no seu início, seja no interior das ciências sociais em construção. No campo filosófico, à parte o movimento espiritualista e o bergsionismo, o catolicismo social fundado sobre os princípios do neotomismo ocupa um lugar importante nas relações de força. Esse último é o resultado de uma grande mobilização católica, em um contexto histórico marcado por vários aspectos.

Durante a segunda metade do século XIX, em um contexto de afirmação do poder e dos valores republicanos e democráticos, a promoção da cultura científica, notadamente das disciplinas humanistas, a Igreja católica e seu Magistério, cuja autoridade temporal declina, se torna, então, o ponto de "concentração" de todos os opositores à República (Henry; Serry, 2004, p. 6). Nesse estado de coisas, a sociologia de Durkheim "incomoda, não somente por suas pretensões positivistas, por seu projeto moral que ela desenvolve, por seus laços com os meios republicanos, mas também, mais amplamente, porque ela propõe um saber global sobre as sociedades humanas" (Serry, 2004b, p. 29). Desse modo, os intelectuais católicos, engajados no apostolado social, não se contentam apenas em se opor à sociologia científica de Durkheim. Orientados pelo tomismo, eles se encarregam de fundar uma "sociologia católica" capaz de concorrer com o projeto intelectual durkheimiano e reconfigurar a Igreja no campo do conhecimento sociológico do social. Mobilizando a filosofia de Santo Tomás de Aquino como elemento central do sistema eclesial - um pensamento que, pelo viés de Aristóteles, emprega certo valor à racionalidade -, a Igreja quer lutar contra a "modernidade" política, cultural e científica (Henry \& Serry, 2004, pp. 7-8). 
Para tanto, vários dispositivos são estabelecidos em colaboração de seus agentes qualificados religiosa e simbolicamente: a Igreja refunda seu sistema eclesiológico (fundado sobre a teologia), cujas instâncias de decisão se encontram sob a autoridade direta do Papa (proclamado infalível em 1870) e de sua administração. No centro desse dispositivo é preciso situar a Encíclica Aeterni Patris (A filosofia cristã), publicada em 1879, na qual Leão XIII recomendava, aos clérigos e aos seus intelectuais católicos, incorporar à doutrina tomista os resultados conquistados pela pesquisa científica contemporânea. Esses dispositivos intelectuais e administrativos são as condições objetivas do catolicismo social, fundadas na Rerum Novarum, proclamada por Leão XIII, em 1891. É nessa Encíclica que Leão XIII impõe uma redefinição das práticas e de intervenções do Magistério católico no mundo social laicizado, pressionado por inúmeras transformações sociais, econômicas e culturais (Serry, 2004b, p. 30).

A sociologia de Durkheim era refutada por unanimidade pelos intelectuais católicos, clérigos ou leigos de todas as gerações, ainda que "as maneiras de se demarcar variem segundo as clivagens que estruturam o subcampo intelectual católico [...] polarizado por suas relações ao tomismo [...] que pode se expressar numa exegese erudita” (Serry, 2004b, p. 30). Para Hervé Serry, a sociologia de Durkheim "propõe um aparelhamento teórico-político que participa da remise en cause do empreendimento social da Igreja no domínio da pedagogia, da família e do Estado" (Serry, 2004b, p. 29).

Todos estes dispositivos en place, o reforço do ensino superior, consolidado pela abertura dos institutos católicos, o recrutamento dos intelectuais, reposicionarão a Igreja no mundo social, que faz apelo a expertises diversas, cujos intelectuais, atraídos pelas pesquisas empíricas alinhados à escola de Frédéric Le Play, estarão no centro do debate frente à sociologia de Durkheim.

Entre os dispositivos, a publicação dos manuais de sociologia católica merece especial atenção. As pesquisas sobre esse objeto têm se tornado uma chave de leitura para compreender os enjeux sociaux em torno do debate entre sociologia durkheimiana e sociologia católica. Reteremos aqui alguns como exemplo, sabendo que somente uma análise mais acurada permitiria compreender e explicar as condições de produção dos manuais de introdução à sociologia católica desse gênero literário, bem como uma análise de conteúdo possibilitaria uma comparação entre os diferentes princípios dessas teorias sociológicas. Isso dito, nós podemos avançar que a publicação dos manuais de introdução à sociologia católica colocados à disposição de seus públicos, difundidos no ensino superior e alhures, funciona como uma estratégia da Igreja católica para redefinir a sociologia científica a partir de princípios cristãos e neotomistas, mas também para recuperar um lugar no debate social, que passa por uma "mise en place de uma expertise credível e argumentada: é preciso mostrar 
que a Igreja dispõe de verdadeiros meios para reduzir a miséria do proletariado" (Serry, 2004b, p. 32). Desse modo, o padre Paul Naudet, jornalista, uma das figuras importantes da "democracia cristâ", publica, em 1899, Premiers principes de sociologie catholique. Ele funda em 1893 a revista La Justice Sociale, tribuna bordelaise e depois parisiense da democracia cristã, que foi interdita em 1908 por Pio x. Seu objetivo no manual é "reunir a grande maioria dos espíritos em torno de uma exposição de princípios claros e nítidos, conforme os ensinos teológicos e as doutrinas sociais da Igreja que Leão XIII havia lembrado quão eloquentes ao mundo, na Encíclica Rerum Novarum, sobre as condições dos operários" (Naudet, 1899, p. 7).

Em seguida outros manuais de sociologia católica foram publicados. Nessa perspectiva, em 1911, Albert Belliot publica o Manuel de sociologie catholique: histoire, théorie et pratique, cujo objetivo é fornecer princípios "de organização de uma sociedade, conforme o catolicismo a partir de solução a aplicar a todos os domínios" (Serry, 2004b, p. 32). Hervé Serry observa que o autor nas 690 páginas jamais cita Durkheim. Por sua vez, Durkheim escreve uma notícia bibliográfica do livro de Belliot no volume 12 de L'Année Sociologique, em que afirma:

É impossível analisar [...] uma obra na qual faltam todos os critérios científicos. Mas não é inútil observar, por exemplo, a maneira pela qual a sociologia é compreendida em certos meios. Spencer nunca é citado; o nome de Comte se encontra uma única vez e nestes termos: Com Comte o individualismo moderno encontrou sua fórmula suprema. Esse último sistema se autoriza cientificamente todos os excessos de ambição e de presunção individual [...] (p. 55).

Nessa mesma orientação, em 1914, o cônego P. Poey publica o Manuel de sociologie d'après les documents pontificaux, à l'usages des Séminaires et des Cercles d'études. Ele define a sociologia católica como "a ciência que tem por objeto as sociedades estudadas nas suas causas a fim de favorecer o aperfeiçoamento, conforme aos ensinamentos da Igreja" (Poey, 1914, p. 2). Nesse livro ele não discute as teorias sociológicas. Contudo, ele precisa, como um duplo eco (paradoxal), por um lado à ciência social e, por outro, à recusa católica das ideias durkheimianas, que o método tomado para reformar as "leis sociais" não consiste em "construir arbitrariamente", mas sobretudo em fundá-las baseado na "observação e na indução" (Idem, p. 8). A ciência social estabelecida por Poey é "essencialmente cristã”. Desse modo, seus fundamentos são:

"A fé e a teologia". É a doutrina católica que ilumina, única e completamente, o labirinto das questões de ordem social e os seus recursos sociológicos. Por conseguinte, é nas mesmas fontes que a sociologia católica busca seus princípios, no Evangelho, nos Padres da Igreja e nos concílios, nos ensinamentos dos Papas e nas lições da história. (Poey, 1914, p. 9). 
Nessa corrente sociologia católica, alguns classificam Paul Bureau (1865-1923), certamente em razão de seu percurso: sociólogo, jurista, membro da École des Sciences Sociales de Frédéric Le Play e "católico fervoroso", e da crítica voltada à obra de Durkheim no seu livro Introduction à la méthode sociologique. Isso contribuiu, talvez, para classificar a obra de Paul Bureau no âmbito do catolicismo social. No entanto, o dossiê da revista Études Sociales, coordenado por Frédéric Audren, enseja esclarecer certos pontos sobre a sociologia de Paul Bureau ${ }^{3}$. Desse modo, por exemplo, Frédéric Audren convida a moderar o quadro esboçado por Hervé Serry (2004b), no que concerne à inscrição de Paul Bureau no domínio da sociologia católica ${ }^{4}$. Audren postula que "o caso 'Bureau' é de natureza a contestar a grande divisão entre o mundo social sugerido por Serry: de um lado uma sociologia católica, empírica conservadora, de inspiração tomista, marcada pela influência de Le Play; de outro a sociologia durkheimiana, racional, republicana e progressista" (Audren, 2005a, p. 6). Audren observa também que, sendo sociólogo e católico, Paul Bureau não cessa, ao longo de sua vida, de dialogar com outras religiōes, com meios socialistas e aqueles de livre pensamento. E ele acrescenta que Paul Bureau, ele mesmo, "rejeita firmemente a ideia de uma "sociologia católica". Julgando-a contraditória, ele deseja que "os universos da ciência e da fé devem continuar absolutamente distintos" (Audren, 2005a, p. 7). No entanto, Frédéric Audren afirma que Paul Bureau pertence a essa geração dos católicos que colocam seus passos não nos de Santo Tomás de Aquino, mas do padre Alphone Gatry'.

Essa nuance deve ser levada em conta, em parte, na medida em que em Paul Bureau nós não encontramos as mesmas apreciações da obra de Durkheim como nos manuais precedentes. Publicado em 1923, ano de seu falecimento, Introduction à la méthode sociologique é uma revisão sobre os princípios e os elementos desse método de análise que ele seguiu durante todos os seus estudos e após trinta e cinco anos. E ele reconhece muito claramente o trabalho de Durkheim. No prefácio, escreve:

Já que eu escrevo aqui o nome desse ilustre professor da Sorbonne, eu tenho a declarar que me lamento ter geralmente combatido as afirmações e as conclusões do autor de As regras do método sociológico, e eu quero render-lhe homenagem à probidade intelectual e ao labor

3. Études Sociales: Paul Bureau et les Sciences Sociales, n. 141, $1^{\circ}$ semestre 2005.

4. Com efeito, Georges Legrand publicou, em 1927, Les grands courants de la sociologie catholique, em que apresenta as tendências da sociologia católica contemporânea, evocando os principais autores e sujeitos de análises. Nesse esboço figura Paul Bureau e "a crise e a restauração da moral familiar".

5. Após ter entrado na École Polytechnique, Alphonse Gatry abandona seus estudos científicos, para estudar Teologia em Strasbourg. Acolhido no meio dos intelectuais católicos, ele é ordenado padre em 1832. Professor de teologia moral no Instituto Católico de Paris e professor na Sorbonne, ele foi eleito, em 1867, para a Academia Francesa. 
enorme desse sociólogo, que foi um verdadeiro professor, um chefe e um líder. Mais do que qualquer outro na França, após trinta anos, Émile Durkheim teve o raro mérito de concorrer ao progresso dos estudos sociológicos, e o vigor do impulso que ele deu foi tal, que esses mesmos que, como eu, denunciaram os erros e os sofismas de sua obra se sentem obrigados a proclamar que eles beneficiaram amplamente esse estado de elã, e guardam um vivo reconhecimento (Bureau, 1923, p. 8).

Após ter feito seus elogios, Paul Bureau esboça as seguintes críticas:

Para sua infelicidade, e nossa, Émile Durkheim viveu em um período pouco propício aos estudos sociais estritamente científicos: ele chegara apenas à idade adulta, no momento em que acontecia, no campo político, a grande batalha entre a moral religiosa e a moral laica e onde o cientificismo dos Taine, dos Renan e dos Berthelot começava a enfraquecer; ele acreditava dever retomar no campo sociológico a tarefa que seus mestres não haviam conseguido. [...] essa preocupação, naturalmente associada no seu espírito aos postulados racionalistas, muito comprometeu o valor científico dos seus trabalhos: ela desviou o curso das suas conclusões para as direções que não resultavam de uma única observação dos fatos; e geralmente muitas interpretações pareceram mais tendenciosas que justificadas. (Bureau, 1923, pp. 9-10).

Paul Bureau, leplaysiano dissidente, republicano, membro do Comitê católico pela defesa do direito, ensinando na Faculté Libre de Droit de Paris, na École des Hautes Études Sociales, borra as clivagens. Desse modo, se sua obra caiu no esquecimento logo após sua morte, são os durkheimianos, dos quais Paul Bureau se aproximou um pouco no final da vida, que mantêm a lembrança desse autor, um dos melhores representantes de Le Play. A esse respeito, merece atenção o artigo de Mélaine Plouviez intitulado "De la Science positive de la morale à la morale sociologique - Paul Bureau, lecteur de Durkheim”, no mesmo dossiê coordenado por Frédéric Audren. Plouviez mostra que é uma tensão entre objetividade e normatividade que Paul Bureau revela na sociologia durkheimiana. Para essa autora, Paul Bureau denuncia na sociologia da moral, tal como propôs Durkheim, uma dupla e contraditória ambição: a objetividade científica e a normatividade moral. Assim, Paul Bureau reconhece a necessidade e a legitimidade da ciência dos costumes; ele recusa a capacidade normativa que seu fundador confere. Paul Bureau afirma que Durkheim não pode, numa mesma sociologia da moral, fundar racionalmente uma ciência positiva da moral e uma moral sociológica. Dito de outra maneira, ele não pode, ao mesmo tempo, ser sociólogo e moralista. A objetividade e a normatividade, para Paul Bureau, constituem duas modalidades discursivas excludentes uma da outra emanando de suas instâncias distintas: a ciência e a metafísica religiosa (Plouviez, 2005, p. 90). 
Outro manual de sociologia importante foi o publicado em 1923 por A. Lorton, sob o título original de Notions de sociologie ${ }^{6}$. Também de inscrição católica, abade, de formação filosófica, tem seu livro prefaciado pelo padre Fleury Lavallée (agrégé de Lettres), reitor das faculdades católicas de Lyon. Notícia bibliográfica em vários boletins e periódicos da época (embora sem recensão), o livro recebe uma resenha na revista L'Année Sociologique , na seção “Sociologie Générale”, subseção “Manuels”. O livro se pretende um manual de sociologia, mas aplicando os princípios católicos às questões morais e sociais. Grosso modo, o livro expõe a doutrina da Igreja católica tal e qual está nas encíclicas Rerum novarum e Immortale Dei, de Leão XIII, e refuta a teoria do materialismo dialético de Karl Marx, este sendo acusado de não "analisar de maneira completa as condições de produção” (Lorton, 1926, p. 29). Além disso, substitui o sistema sociológico de Durkheim e do Année Sociologique pelas teorias sociológicas da escola histórico-cultural (representada por P. Schmitt, Graebner, Mgr. Le Roy). Um ponto central opõe a moral inspirada da doutrina católica (originada de Deus, razão soberana) à moral pensada por Durkheim, que Lorton classifica como falsa, uma vez que para Durkheim a moral emana diretamente da sociedade.

Não poderemos aqui desenvolver a configuração do neotomismo belga, para entender como a sociologia durkheimiana será recebida no meio católico num país vizinho, onde o neotomismo se pretendeu uma referência.

É importante, contudo, lembrar aqui uma figura central do neotomismo francês. Trata-se de Jacques Maritain.

No transcurso dos anos 1910, o pensamento de Bergson ganha algo de paradoxal ${ }^{8}$. Precedentemente, sua sólida reputação entre os especialistas se reforça em meados de 1910 de um prestígio e de uma celebridade sem precedentes no que concerne a um filósofo. À parte um público mundano, seus cursos atraem a atenção considerável de inúmeros intelectuais e escritores, tais como Charles Péguy, Ernest Psichari, Jacques e Raïssa Maritain, Massi ou ainda George Sorel. Mas esse sucesso contribui para múltiplas polêmicas a seu respeito (Serry, 2004a, p. 76). Se para Bergson a metafisica é

6. Este será rapidamente traduzido e adaptado ao Brasil, em 1927, sob o título Sociologia: compêndio escolar para o Curso Gymnasial, pela Livraria Alves/Paulo Azevedo e Cia. Coleção Pedagógica, Livros Didáticos, que reunia professores da FTD.

7. L'Année Sociologique, tome I, 1923-1924.

8. Entre as críticas de filósofos à sociologia durkheimiana, uma das principais vem das tradições metafísicas e espiritualistas. A oposição mais emblemática se faz entre Bergson (que se inscreve na tradição do espiritualismo de Ravaisson) e Durkheim (marcado pelo neokantismo e o racionalismo de Renouvier), na medida em que Henri Bergson fez uma trajetória similar à de Durkheim, no que concerne à trajetória religiosa (judaica), à formação escolar (École Normale Supérieure, Agrégés de Philosophie) e a seus interesses por temas como a religião e a moral; ainda que suas posições teóricas os distanciem no campo da filosofia e da sociologia. 
sinônimo de filosofia, devendo ser superada pelos puros conceitos e chegar à intuição, penetrando até à mais profunda das coisas, pois ela é o conhecimento do absoluto, para Jacques Maritain a filosofia é sinônimo de neotomismo. Desse feito, assim como não existirá alguém que tenha sido tão forte quanto Bergson no projeto de reabilitação da metafisica, nenhum filósofo terá a eficiência de Jacques Maritain no empreendimento do retorno à filosofia de Santo Tomás de Aquino. Maritain, pode-se dizer, articula melhor o projeto da instituição católica imposto ao seu Magistério romano.

Como se observa, Maritain consagra um meticuloso estudo sobre a Suma Teológica. Após publicar vários artigos em periódicos católicos especializados, recebe o encargo de Humbert Clérissac (padre dominicano, próximo da Action Française ${ }^{9} \mathrm{e}$ seu diretor espiritual) para proferir várias conferências sobre a filosofia de Bergson. Seus cursos no Institut Catholique de Paris (um centro do neotomismo na França) na primavera de 1913 desfrutaram de grande sucesso. As críticas que ele faz a Bergson ressoam poderosamente, uma vez que este está no centro da atualidade intelectual e é objeto de campanha contra seu pensamento. Assim, Maritain, pela crítica ao seu ex-mestre, se torna uma espécie de líder do neotomismo. A publicação de seu livro La philosophie bergsonienne, em que ele retoma os ataques a Bergson, confirma o lugar conquistado, em pouco tempo, pelo filósofo (Serry, 2004a, p. 79).

Para Maritain, o erro inicial da nova filosofia consiste na "intuição da durée", que nos forneceria a introspecção. Ele postula que haveria uma deformação de certas teses escolásticas no bergsonismo que conduziria a uma espécie de "niilismo intelectual" no modernismo e ao pragmatismo na religião (Maritain, 1914, p. 428). Certamente a proximidade de Bergson com William James e seu pragmatismo foi um ponto negativo na apreciação de Maritain da filosofia de Bergson. Para Maritain, a única salvação é se livrar de Bergson e retornar à "escolástica tomista" (Idem, p. 430).

Desse modo, Maritain declara guerra ao pensamento modernista. Em 1922, ele publica uma coletânea de artigos intitulada "Antimoderno", na Revue de Jeune. Ele designa o tomismo como uma verdadeira filosofia da humanidade para todos os tempos. Criticando a Renascença, a Reforma Protestante e o Cartesianismo como "aberrações intelectuais", na medida em que elas exigem uma ruptura com a Escolástica, ele encontra nessa última a expressão mais pura, e a mais universal.

Jacques Maritain não hesita em propor como princípios espirituais do mundo moderno as encíclicas Syllabus e Pascendi. Para ele, o "renascimento cristão" será

9. Movimento intelectual e político nacionalista e monarquista de extrema-direita, fundado na França em 1899, no período do L’Affaire Dreyfus, com o objetivo de reforma intelectual do nacionalismo. Encontra em Charles Maurras, escritor e teórico do nacionalismo integralista, um ideólogo do estabelecimento de uma monarquia antiparlamentar. O movimento se expressa por meio de um jornal do mesmo nome, Action Française, criado em 1908 e publicado até 1944. 
efêmero e sem vigor se não for, antes de tudo, um "Renascimento tomista", que tem por condição uma fidelidade rigorosa não somente aos princípios gerais, mas aos menores princípios filosóficos de Santo Tomás. Trata-se, para Maritain, de um vínculo servil a Santo Tomás de Aquino e a Aristóteles, de uma maneira filosófica, que consistiria em repetir suas fórmulas de modo mecânico. Trata-se de uma fidelidade espiritual e filial, que faz buscar, em seus princípios ativamente meditados, grupos, meios de descobrir, de "inventar" a solução de problemas novos graças a um esforço original do espírito. "Sejamos fiéis a Santo Tomás como uma graça de Deus", dizia ele, em De quelques conditions de la Renaissance thomiste.

O que se vê nesse cenário é a retomada da Santa Sé de um espaço eclesial que a reposicione, por conseguinte, no espaço social, agita o modernismo apoiando-se sobre o retorno ao tomismo pregado desde a Encíclica Aeterni Patris (1879). Para tanto, muitos dispositivos serão estabelecidos, formando uma grande estrutura do ensino superior. Alguns exemplos são clássicos como: l'Institut Catholique de Paris, l'Université de Louvain, na Bélgica e o Colégio Angélico, em Roma. Ora, o neotomismo é um movimento de dimensões internacionais. Ele é "uma fonte central" para todos aqueles que querem "se impor no campo da expertise da sociedade" (Serry, 2004b, p. 33). É desse modo que na Bélgica, um dos grandes berços do neotomismo europeu, vários dispositivos foram estabelecidos. O Institut Supérieur de Philosophie de Louvain de l'Université Catholique de Louvain foi criado em 1889, pelo cardeal Déziré-Joseph Mercier (1851-1926) para ser um dos centros da filosofia tomista. Mercier é o autor da carta de intenção da Revue Néo-Scolastique (programa fundador), ou seja, a "Introdução" do número fundador dessa revista, em 1894. Esse artigo enfatiza que, no movimento de renascimento escolástico, "Leão XIII contribuiu enormemente pela Encíclica Aeterni Patris que recolocou de volta a honra da filosofia dos grandes mestres da Escolástica e a conduziu à unidade do ensino nas escolas católicas" (Mercier, 1894, pp. 6-7). Desse modo, a escola de filosofia da Universidade de Louvain, fundada sob encomenda por Leão XIII, é "situada sob a invocação daquele que parece se acordar melhor e mais sabiamente ao espírito de análise e ao espírito de síntese de Santo Tomás de Aquino" (Idem, p. 17).

Nesse centro de filosofia neotomista e na esteira de Mgr Mercier, destaca-se Simon Deploige (1868-1927), doutor em Filosofia, Letras e Direito. De formação e tradição filosófica neotomista, Deploige, reconhecido como grande intelectual católico, exerce um papel importante e se situa como uma figura com prerrogativas à altura de rivalizar com Durkheim no campo intelectual. À parte as cartas trocadas entre os dois homens, é sobretudo no livro Conflits de la morale et de la sociologie, publicado em 1911 na mesma editora (Félix Alcan) pela qual Durkheim publicara seus livros e sua revista L'Année Sociologique, que Deploige responde às críticas de Durkheim 
(e, também, de Lévy-Bruhl) sobre a moral tomada para estabelecer sistemática e metodologicamente uma ciência dos costumes vinculada à sociologia. Dito isso, o importante artigo de Guillaume Cuchet, sobre a recepção d'Asformas elementares no meio católico ${ }^{10}$, indica que o caso Deploige-Durkheim ${ }^{11}$ é apenas um caso entre outros, deflagrado pela crise do modernismo, advinda no final do século XIX e início do XX, que marca a separação do Estado e a Igreja, o que vai influenciar a recepção do livro de Durkheim pelos católicos.

Digno de observação é o fato de que o Prefácio à terceira edição do livro Le conflit de la morale et la sociologie, de S. Deploige, seja assinado por Jacques Maritain. Para Maritain, a obra de Deploige "continua um estudo histórico e crítico, o mais exato e o mais rebuscado da sociologia contemporânea, de sua gênese, de seus postulados, de seu método [...], em particular, solidamente documentado, das origens alemãs do sistema de Durkheim" (Maritain, 1923, p. XVIII). Retomando a apreciação de Georges Gayou, ele afirma que "um dos méritos de seu livro é de colocar a lume a posição ao mesmo tempo original e dominante do pensamento tomista em relação ao individualismo da falsa metafísica liberal e ao amoralismo da falsa ciência sociologista" (Idem, p. XIX).

Cabe ainda frisar que Jacques Maritain lecionou no Institut Supérieur de Philosophie, da Université Catholique de Louvain. Os laços entre Maritain e Deploige "mostram que a démarche de Simon Deploige se inscreve na defesa de um 'edifício tomista' contra o 'potente ataque' dos sociólogos. Um 'edifício' que se mantém 'sólido' e bastante hospitaleiro para abrigar a sociologia, mas uma sociologia que pode estabelecer uma 'colaboração útil' com a filosofia moral" (Fournier, 2007, p. 761; Deploige, 1927, p. 351).

10. "La réception catholique des Formes élémentaires de la vie religieuse (1912) d'Émile Durkheim". Archives de Sciences Sociales des Religion, 159: 29-49 (Cuchet, 2012).

11. O capítulo Iv do livro Conflits de la morale et de la sociologie, intitulado "La genèse du système de M. Durkheim”, e o capítulo v, "Le réalisme social", são de início publicados respectivamente entre 1905 e 1907 na Revue Néo-Scolastique (t. XIv, p. 329ss). Na ocasião da publicação do livro em 1911, foi também a da obra de Lucien Lévy-Bruhl La morale et la science de mours, que reivindicava sua inscrição na sociologia durkheimiana. Através de duas cartas à Revue Néo-Scolastique (de 20 de outubro e de 8 de novembro de 2007), Durkheim responde às críticas de Simon Deploige, que o acusava de ter "simplesmente retomado a teoria de Wundt sobre os fins morais". Durkheim afirmava o seguinte: "Eu devo, certamente à Alemanha, mas eu devo, muito mais aos historiadores do que aos economistas, e aquilo que M. Deploige parece não duvidar: eu devo ao menos o mesmo à Inglaterra". Na continuidade da resposta a S. Deploige, Durkheim dizia: "Eu devo, primeiro ao meu mestre M. Boutroux, que, na École Normale Supérieure, nos repetia frequentemente que cada ciência deve se explicar por 'princípios próprios' como diz Aristóteles, a psicologia por princípios psicológicos, a biologia por princípios biológicos. Muito penetrado dessa ideia, eu a apliquei à sociologia”. 
Os intelectuais e o neotomismo no Brasil: agências e agentes

Busca-se nessa seção compreender em que medida e através de qual mecanismo se difundiu, no Brasil, o neotomismo francês, que se tornou, como na França, a base do pensamento social católico.

No Brasil, no decorrer do século Xx, existe uma diversificação das correntes filosóficas tais como: o espiritualismo, a filosofia católica, o culturalismo, a fenomenologia, o existencialismo, o marxismo e o neopositivismo. Entre essas, figura a filosofia católica. Mas é, sobretudo, o espiritualismo de Raimundo de Farias Brito (1862$1917)^{12}$ que caracteriza o pensamento filosófico no Brasil, nos primeiros anos desse século. Farias Brito exerce um papel no Brasil equivalente ao de Bergson na França. Ele marca profundamente o pensamento do seu mais fiel e importante discípulo, Jackson de Figueiredo (1891-1928) ${ }^{13}$, o qual, ainda que não tenha formulado uma rigorosa proposição filosófica como seu mestre, elaborou, contudo, um pensamento muito conservador centrado nas ideias de ordem e de autoridade. Esse pensamento serviu de base teórica aos católicos para assimilarem as instituições republicanas e estabelecerem um diálogo com outras concepções políticas, superando o dogmatismo ultramontano no qual a Igreja católica se estabeleceu após a Proclamação da República em 1889. A presença significativa de uma filosofia católica constituiu uma reação expressiva contra os valores republicanos fundados sobre um pensamento positivista (Padilha \& Velez, 1998).

Para enfrentar a consolidação do poder republicano, a Igreja católica, apoiada por certos filósofos e intelectuais, implementou alguns dispositivos institucionais necessários. Isso significou uma estratégia de reconversão social e simbólica para aumentar o poder político e institucional na divisão do trabalho de dominação, constituindo uma rede de organização gerada por intelectuais leigos sob o controle do alto clero. É oportuno lembrar que a expansão desse projeto resultou não somente das estratégias e diretrizes do Vaticano (antimodernista) para lutar contra a emergência do pensamento moderno no Brasil, em uma época de desenvolvimento dos movimentos operários na Europa, mas pela tomada de consciência, dos bispos brasileiros, da crise

12. Raimundo Faria de Brito (1862-1917), foi um escritor e filósofo brasileiro, filho de Marcolino José de Brito e Eugênia Alves de Farias, nascido em São Benedito (Estado do Ceará). Seus estudos secundários foram feitos em Sobral, depois em Fortaleza (capital do Estado). Formou-se na Faculdade de Direito de Recife, onde foi aluno de Tobias Barreto. É considerado um dos maiores filósofos brasileiros do final do século XIX, cuja filosofia, muito original, é marcada pela metafísica tradicional e o espiritualismo.

13. Jackson de Figueiredo (1891-1928) foi advogado, formado em Direito na Faculdade Livre de Direito, no Estado da Bahia. Trabalhou como jornalista, crítico literário, filósofo e político. Após sua conversão ao catolicismo, tornou-se uma das figuras principais da organização do movimento católico brasileiro. 
que atravessava os grupos dirigentes no interior do país e das transformações sociais e econômicas em vários setores da sociedade brasileira (Miceli, 2001, p. 127).

Esses elementos mostram, desde então, a aliança conservadora formada entre o poder eclesiástico, de uma parte para reforçar seu poder no espaço social, e os intelectuais leigos que buscam estrategicamente, de outra parte, uma reconversão de seu capital simbólico, tendo por objetivo a reação anticientista. Isso deve ser situado numa perspectiva mais ampla de transformações da configuração da relação entre campo literário, campo eclesiástico, instalação das instituições de ensino superior e desenvolvimento de movimentos sociais no seio da sociedade brasileira. Nessa configuração aparece o neotomismo de forte penetração no campo intelectual brasileiro, do qual Leonel Franca ${ }^{14}$ (jesuíta) e Alceu Amoroso Lima são os maiores representantes.

O padre Leonel Franca (1838-1948) está na origem de toda a filosofia neotomista que inspira os primeiros passos da filosofia católica no Brasil. Apoiado sobre uma sólida formação em ciências humanas, sua influência se estendeu da filosofia à educação. Ele faz parte da comissão nomeada por dom Sebastião Leme (juntamente com Amoroso Lima), encarregada de fundar a Universidade Católica do Rio de Janeiro, em $1941^{15}$, uma das mais prestigiosas do Brasil. A Faculdade de filosofia dessa universidade, dirigida pelos jesuítas, torna-se o mais importante centro de estudos filosóficos e tomistas. Ela edita, na época, a revista Verbum, um outro importante veículo de difusão da filosofia tomista no Brasil. É no Rio de Janeiro também que se situa a Sociedade Brasileira de Filosofia Católica, que publica a revista Presença Filosófica. Desse feito, a cidade do Rio de Janeiro se torna o grande centro da filosofia tomista. Em seguida outros centros acadêmicos e intelectuais são estruturados, como por exemplo, em Minas Gerais e São Paulo (Campos, 1998, p. 72).

Para resumir, enquanto conselheiro número 1 de personalidades e de instituições importantes, Leonel Franca elaborou uma filosofia da cultura no seu opus magnum, $A$ crise do mundo moderno. Sua filosofia neotomista se fundamenta na visão de Joseph Maréchal, Sertillanges, Pierre Rousselot e Etienne Gilson. Muito inteirado da ciência de sua época, ele busca uma síntese entre razão e fé, em harmonia com a teoria da doutrina católica.

14. Leonel Edgar da Silveira Franca (1893-1948) foi um padre brasileiro, pertencente à Companhia de Jesus. Ele fez seus estudos em filosofia e teologia, em Roma, na Pontifícia Università Gregoriana.

15. Devemos lembrar que em 1932, antes da fundação da universidade católica, foi criado o primeiro Instituto Católico de Estudos Superiores (Ices), inspirado por Alceu Amoroso Lima, ligado ao Centro Dom Vital. Essa instituição ensejava não somente formar católicos, mas participar nas discussões sobre o ensino superior e reforçar o papel da Igreja na formação das elites (Almeida, 1989). O núcleo de formação era centrado sobre três disciplinas: sociologia, filosofia e teologia. Amoroso Lima e Dom Helder Câmara, ex-bispo de Olinda (Recife), Estado de Pernambuco, faziam parte do corpo docente. 
Quanto a Alceu Amoroso Lima (1893-1983), a morte prematura de Jackson de Figueiredo, diretor do Centro Dom-Vital, em 1928, confere-lhe uma grande notoriedade. $\mathrm{O}$ que veremos mais adiante.

No que concerne à relação da Igreja com o campo intelectual no Brasil, duas agências de enquadramento ideológico formam o núcleo onde a Igreja recruta seus porta-vozes: o Centro Dom Vital e a revista $A$ Ordem. Os dois órgãos iniciaram suas atividades sob a direção de Jackson de Figueiredo. Na medida em que essas instâncias exerceram um papel muito importante na produção do pensamento cultural católico e serviram de círculo da intelligentsia brasileira católica, é importante enfatizar alguns aspectos característicos desses órgãos. Vejamos alguns traços das linhas editoriais da revista, que revelam seu projeto intelectual ${ }^{16}$.

O Centro Dom Vital é uma associação de estudo, discussão e apostolado, subordinada à Igreja católica, fundada em 1922, no Rio de Janeiro, por Jackson Figueiredo, com a colaboração do arcebispo coadjuntor do Rio, dom Sebastião Leme da Silveira Cintra ${ }^{17}$. Até à fundação da Pontifícia Universidade Católica do Rio de Janeiro em 1941, o Centro foi considerado o principal núcleo intelectual do catolicismo brasileiro. Funcionando sob a supervisão de autoridades eclesiásticas, foi tido como uma associação elitista, cujo objetivo mais importante consistia em recrutar para a Igreja intelectuais do país e formar uma nova geração de intelectuais católicos. Jackson Figueiredo foi o primeiro presidente do Centro. O primeiro assistente eclesiástico foi o padre jesuíta Leonel Franca. As principais atividades do Centro na década de 1920 foram a promoção de conferências de teologia e filosofia, a edição de uma revista mensal, $A$ Ordem, fundada em 1921, e a manutenção de uma biblioteca católica administrada por Augusto Frederico Schmidt (1906-1965) ${ }^{18}$.

16. Alguns estudos foram realizados em vista de explicar a formação do pensamento católico e a história social do campo intelectual brasileiro. Fazemos referência aqui ao artigo que se tornou um clássico, e um dos pioneiros sobre a questão: "A Ordem: uma revista de doutrina, política e cultura católica" (Veloso, 1978, pp. 117-160).

17. Sebastião Leme da Silveira Cintra, Cardeal Leme, como era conhecido, nasceu em 1882, no Rio de Janeiro, e morreu em 1942. Do lado paterno era de origem flamenga Leme, transferida para São Paulo no século XVI. As gerações mais próximas eram constituídas de pequenos proprietários rurais. Do lado materno, era de origem portuguesa, fixada no Brasil no século XVIII, que detinha razoável fortuna da mineração do ouro em Pitangui, em Minas Gerais. Em 1896, viajou para Roma. Ficou hospedado no Colégio dos Jesuítas, onde estudou Humanidades, ao mesmo tempo que estudou filosofia na Universidade Gregoriana. Em 1900 recebeu o título de doutor em filosofia e iniciou em seguida o curso de Teologia. Em 1904 recebeu as ordens maiores. Foi arcebispo de Olinda e Recife e do Rio de Janeiro. Foi o segundo cardeal brasileiro (CPDOC/FGV).

18. Augusto Frederico Schmidt nasceu em 1906 no Rio de Janeiro, e morreu em 1965. Seu pai tinha origens de família abastarda e estudou na Inglaterra. Sua mãe, baiana, era culta e inteligente, cuidou da orientação literária dos filhos. Seu avô paterno tinha casa de tecido no Rio de Janeiro, e seu avó materno era contador na loja comercial do seu avô paterno. Augusto Frederico Schmidt foi um poeta e 
Após a fundação dessa instituição, outros centros e publicações foram criados (Abreu et al., 2001).

A revista $A$ Ordem, fundada em 1921, é um periódico de difusão da doutrina política e cultural católica e constitui um dos principais veículos de divulgação da ideologia do grupo católico. Sua história, que se confunde com a do Centro Dom Vital, se divide em dois grandes momentos: o primeiro concerne aos anos 1921 a 1928, sob a direção de Jackson de Figueiredo, em que a ênfase é colocada sobre a doutrina política religiosa. Os discursos são fundados no pensamento conservador dos intelectuais franceses, tais como Charles Maurras, Joseph de Maistre, Louis Bonald, e constituem um contra-ataque ideológico ao liberalismo, ao comunismo e às ideias renovadoras no plano da educação e da pedagogia, no momento da implantação da educação laica no Brasil. Nesse período, anos de 1920, a elite católica concentrava seus esforços na luta contra a autonomia do Estado laico, o avanço do protestantismo, a inércia de um grupo católico e a recondução da Igreja no centro de decisões políticas nacionais. Ora, era inaceitável, para uma grande parte dos alunos, dirigente do catolicismo brasileiro, num país majoritariamente católico, a Igreja se manter longe de universos de decisões políticas, em razão de uma intelectualidade marcada pela ciência e pelo anticlericalismo (Daros \& Pereira, 2015, p. 265).

A segunda fase da revista $A$ Ordem compreende os anos de 1928 a 1939, após a morte de Jackson de Figueiredo. Alceu Amoroso Lima, marcado por esse último, será consagrado por monsenhor Sebastião Leme, como aquele capaz de substituir e continuar a obra de Jackson de Figueiredo. Nesse novo período, a revista consagra pouco espaço às questões políticas. Os artigos dão prioridade às questões religiosas, filosóficas e políticas, aparentemente sem tomadas de posição por um partido político. Novas seções da revista são criadas para ampliar os debates culturais, ainda que a questão religiosa seja central, uma estratégia para recrutar os intelectuais (Velloso, 1978, p. 132).

Monica Velloso (1978) observa que a sociologia se torna nesse período um objeto que atrai a atenção da revista $A$ Ordem. Alceu Amoroso Lima não hesita em apresentar o ensaio "Apologética e sociologia de Tourville" (alguém próximo de Frédéric Le Play, adversário de primeira hora de Durkheim), no qual analisa o método científico de Tourville, aplicado à sociologia, à filosofia e à religião. Tourville é percebido por Amoroso Lima como um autêntico representante da sociologia, notadamente

escritor importante da segunda geração do modernismo brasileiro e chegou a ser assistente do governo de Juscelino Kubitschek, para quem preparou grandes discursos, inclusive o memorável " 50 anos em 5”. Jackson de Figueiredo, de quem Schmidt se tornou próximo, exerceu grande influência sobre este último (CPDOC/FGV). 
em razão de sua sociologia da família estar em oposição à sociologia do indivíduo (liberalismo) e do Estado (socialismo e capitalismo social).

No que concerne à filosofia, a revista consagra nesse período um grande espaço a Aristóteles, Leibniz, Santo Tomás de Aquino e Santo Agostinho. Em 1929, na ocasião dos cinquenta anos da Encíclica Aeterni Patris (1879), de Léon XIII, a revista consagrou um número especial à filosofia tomista. Esta é concebida pelos responsáveis e colaboradores da revista como a síntese do pensamento cristão, sempre atual, imperecível, imutável, em oposição à esterilidade do idealismo das outras correntes filosóficas (Velloso, 1978, p. 133).

Os anos 1930 mostram as fortes mobilizações da Igreja para colocar em obra os movimentos da Action Catholique, empreendimento eclesiástico para ganhar terreno no espaço social e aumentar seu poder na luta do saber sobre questóes sociais que se colocavam nesse momento em vários países europeus, segundo o projeto do Vaticano. Assim, em junho de 1936, os bispos brasileiros tornam público o status da Ação Católica, que se inspira diretamente no modelo italiano. Essa organização relembra a organização política fascista que havia também servido de modelo para o partido "integrista" (Miceli, 1981, p. 50).

A seguir discutiremos alguns elementos do pensamento de Alceu Amoroso Lima e o essencial da sociologia que ele projetou construir. O objetivo é identificar, na sociologia de orientação católica, como a sociologia de Durkheim é percebida e confrontada.

\section{Alceu Amoroso Lima: trajetória e estratégias de reconversão simbólica}

Algumas propriedades sociais são importantes para termos uma compreensão do universo social no qual Amoroso Lima é formado e o peso decisivo de um conjunto de "disposiçôes duráveis" (Bourdieu) que o erige como um dos mais importantes do campo intelectual brasileiro no final do século XIX e início do XX.

Filho de comerciante industrial, ele fez seus estudos primários em casa (uma prática das famílias que dispunham de um capital social e econômico na época), sob a orientação do professor João Kopke, fundador da "Escola Nova do Brasil", e os estudos secundários no Colégio Pedro II, então Ginásio Nacional, um dos colégios mais prestigiosos do Brasil. Alceu terminou os estudos secundários em 1908. No ano seguinte, entrou na Faculdade de Ciências Jurídicas e Sociais do Rio de Janeiro. Em 1911, ainda estudante, começou a trabalhar em um escritório de advocacia com João Carneiro de Sousa Bandeira (advogado, diplomata, ensaísta e professor), tio do poeta Manoel Bandeira (1886-1968). Nesse mesmo período, torna-se diretor da revista $A$ Época, em que publica seus primeiros textos e comentários jurídicos. 
Em 1913, volta pela terceira vez à Europa, onde entra em contato com o escritor José Pereira da Graça Aranha, que lhe propóe organizar uma associação cultural no Brasil, que se chama Goethe, voltada para os intelectuais. Durante sua permanência em Paris, ele frequenta, na Sorbonne, no Collège de France e no Institut Catholique de Paris, cursos de filósofos importantes como Bergson e Jacques Maritain. Como vimos anteriormente, na primavera de 1913, o curso de Maritain fará grande sucesso. Muito influenciado por Figueiredo, após sua conversão (1928), Amoroso Lima assume a direção do Centro Dom Vital e a edição da revista $A$ Ordem. No entanto, modificando as orientações e distanciando essas instituições do aspecto político de Figueiredo, ele se engaja na busca de uma universalidade, com base em uma óptica neotomista. Nas suas Memórias improvisadas (1973, pp. 144-149), Amoroso Lima explica como recebeu a influência de Bergson, que o conduziu em direção ao espiritualismo: "ao retornar ao Brasil (em fins de 1914), depois de demorada permanência em Paris, vinha imbuído das ideias de Bergson, do seu espiritualismo evolucionista, de seu vitalismo criador" (Lima, 1973, p. 145). Mas em seguida ele se deixou influenciar, sobretudo, pela filosofia neotomista de Jacques Maritain, que marcará toda a sua vida.

Os anos que seguem após 1940 serão os da consolidação do processo de institucionalização das ciências sociais no Brasil, com abertura de vários centros de pesquisas empíricas e a criação de instituições de ensino superior. Alceu Amoroso Lima exerceu um papel importante para o desenvolvimento de uma corrente chamada "sociologia católica". Seu projeto é deslegitimar a sociologia universitária durkheimiana. Dito de outra maneira, tentando retirar a sociologia do domínio do positivismo, Amoroso Lima propôs redefinir a disciplina a partir dos princípios cristãos e tomistas. Ele se opõe claramente à sociologia dos fatos sociais, tais como queria Durkheim, e estima que exista "uma possível compatibilidade entre os postulados cristãos e a reflexão racionalista sobre a vida social inspirada em Frédéric Le Play e Jacques Maritain” (Meucci, 2011, p. 70).

Amoroso Lima, como vimos, participa em 1941 da fundação da Universidade Católica do Rio de Janeiro, onde se torna professor de literatura brasileira, até sua aposentadoria, em 1963. Foi nomeado representante do Brasil durante o concílio do Vaticano II, acontecimento que o marca profundamente. Entre os anos 1930 e 1934, ele se interessa pelos estudos de economia e de sociologia. Nessa época, relendo Jacques Maritain, inspira-se na democracia cristã, a democracia social, a partir do "humanismo integral" ${ }^{19}$. Ele estima que nesse período a literatura sobre as questôes

19. Humanismo integral é o título de um livro de Jacques Maritain, publicado em 1936, ano da guerra civil na Espanha, do front popular na França e da subida do regime totalitário na Europa. Nesse livro, 
sociais era quase ausente. A ausência dessa literatura nas áreas de sociologia e economia aparece para ele como uma oportunidade de investir na literatura do ensino social da Igreja. Segundo ele, a ocasião da publicação da Encíclica Quadragésimo Anno, de Pio XI, em 1931, comemorativa da Rerum Novarum, impõe uma visão da posição da Igreja no Brasil sobre a realidade social e política. Daí seu interesse pela sociologia e pelo estudo do problema da burguesia. Alceu busca dissociar o espírito burguês do espírito cristão. Para ele, a burguesia caminha numa direção oposta à filosofia cristã. Estes livros publicados por ele, Esboço de introdução à economia moderna (1930), Debates pedagógicos (1931), Preparação à sociologia (1931), Oproblema da burguesia (1932), Pela reforma social (1932), Politica (1932), O senhor Fernando de Azevedo e sua sociologite aguda e o que mais lhe aconteceu (1936), são todos impregnados de ideias sociais e políticas de Jacques Maritain (Lima, 1973, pp. 148-149).

Com efeito, a entrada de Amoroso Lima nesse domínio da sociologia vem como uma estratégia de se reposicionar no campo intelectual. Após alguns fracassos com uma estratégia como na promoção de cargos universitários, ele tenta várias atividades em diferentes domínios, inclusive no domínio da indústria, empreendimento de seu pai. Reportamo-nos às suas Memórias improvisadas para confirmar o exposto acima:

Só muito tarde, em 1930, depois de estagiar na advocacia, na diplomacia, na própria indústria, e de ingressar em 1919 no jornalismo literário - é que Augusto Frederico Schmidt me animou a disputar um concurso para a cátedra de sociologia na então Escola Normal, hoje instituto de Educação. Minha inscrição causou surpresa. E até indignação. A Sociologia era então considerada um feudo "positivista". Aconteceu até mesmo o seguinte episódio cômico. Um dos candidatos, o Professor Lupércio Hope, meu antigo professor de matemática, enviou um ofício ao diretor da Escola, Professor Carlos Werneck, protestando contra minha inscrição, "por ser católico" [...].

[...] Foi então que acedi ao convite de Fernando de Azevedo, na época diretor da Instrução Pública no Rio, a participar da banca examinadora do concurso para a cátedra de Literatura Brasileira, junto a Coelho Neto, Nestor Vítor e Antenor Nascentes. Era o meu ingresso no ambiente universitário, não mais como aluno, mas como candidato a professor... Por causa da Revolução de Outubro, o concurso de Sociologia afinal não se realizou. Mesmo depois da apresentação das teses, inclusive a minha de Introdução à economia moderna, que certamente seria contestada desde o título e o tema. Como dois anos mais tarde, em 1932, o seria minha Economia pré-politica apresentada ao concurso para a cátedra de Economia Política, já agora

Maritain preconiza uma nova cristandade, uma cristandade profana, dez anos após a condenação nacionalista da Action Française. 
na Faculdade Nacional de Direito. Economia dos “primitivos”, não era economia política na opinião do Professor Inácio de Azevedo Amaral, um dos arguidores.

Classificado em segundo lugar (Leônidas de Resende, meu ex-colega no curso de Direito, é que tirou a cátedra), não desisti. No ano seguinte me preparei para o novo concurso na cátedra de Introdução ao Direito, na mesma faculdade com uma tese sobre Introdução ao Direito Moderno. Foi Hermes Lima que venceu a competição. Viria ainda a disputar um concurso, em 1947, com uma tese sobre $O$ crítico, para a cátedra de Literatura Brasileira, já agora na Faculdade Nacional de Filosofia, para a qual fora nomeado interinamente pelo Ministro Gustavo Capanema [...]. Dessa vez entrei, talvez por não se apresentarem outros competidores. Desde 1929, entretanto, como presidente do Centro Dom Vital começara a me exercitar no magistério particular num curso sobre Sociologia e a doutrina social da Igreja. Especialmente a partir de 1931, depois da publicação da Encíclica Quadragesimo Anno [...].

Quando em fins de 1937, aceitei a sucessão de Afonso Pena Júnior, como reitor da Universidade do Distrito Federal, assumi também a cátedra de Sociologia. Ainda o meu catolicismo ia ser "uma pedra no caminho". Percebi que um dos meus alunos vivia me interpelando durante as aulas... Também durou pouco tempo esse meu curso... Em meados do ano, deixei a reitoria e a cátedra nessa universidade. Continuei apenas com aulas de Sociologia, na Faculdade de Serviço Social, que se fundara no Rio, a primeira no Brasil depois de São Paulo, no Instituto de Educação Familiar e Social, patrocinado pelo Cardeal Leme, sob a direção de religiosas francesas de um instituto secular sem hábito especial, e que por muito tempo eu mesmo não soube que pertenciam a uma Congregação Religiosa.

Só em 1941, com a fundação da Faculdade Nacional de Filosofia, é que assumi, até me aposentar em 1963, a cátedra de Literatura Brasileira. Já então assumira também nas Faculdades Católicas, que se transformaram na Pontifícia Universidade Católica do Rio de Janeiro, a mesma cátedra de Literatura Brasileira.

Guardo desses quarenta e quatro anos de ensino universitário, tanto em institutos particulares como em faculdades públicas, a mais cara e inesquecível das recordações. Todas as demais tentativas profissionais constituíram meros ensaios, nesse drama comum da procura de uma vocação particular. Penso que a minha era essa. Só lamento não me ter preparado sistematicamente para a profissão. E de nela ter ingressado e sempre me mantido como autodidata, com esse espírito amadorístico, que terá sido porventura a nota típica, com seus percalços e também suas vantagens, de toda a minha vida intelectual (Lima, 1973, pp. 223-224).

Como podemos observar nesse longo depoimento, oriundo de uma família abastada social e economicamente, após os fracassos acumulados, Amoroso Lima investe seus trunfos na consagração enquanto leadership católico e como professor universitário. Sua entrada na Faculdade de Direito do Rio de Janeiro foi vista não somente como um prêmio de consolação, conversão do capital social e simbólico; 
o projeto era promover uma sociologia católica. Contudo, o sucesso de Amoroso Lima em parte se deve não somente às condições objetivas, mas às transformações de seus privilégios em recursos culturais. Isso permite a Amoroso Lima adquirir um certo conhecimento dos móveis de lutas e concorrência no campo intelectual e seu funcionamento. Como mostrou Sergio Miceli:

Os concursos havidos na Faculdade de Direito do Rio de Janeiro no início da década de 1930 revelam, por outro lado, os móveis centrais das lutas no campo intelectual da época, na medida em que permitiam aferir o valor social atribuído aos intelectuais e o estado da concorrência em relação às posições mais cobiçadas. O móvel da concorrência entre os candidatos às cátedras deslocou-se do terreno estritamente jurídico para a esfera das teorias políticas e sociais acerca do papel do Estado. O confronto entre os defensores de uma posição materialista e os porta-vozes de uma postura espiritualista que se manifesta por ocasião do concurso para a cátedra de economia política, ao qual se apresentaram Leônidas de Rezende (com a tese Formação do capital e seu desenvolvimento) e Alceu Amoroso Lima (com a tese Ensaio sobre a economia pré-politica), ressurge no momento do concurso para a cátedra de introdução à ciência do direito, ao qual se apresentaram dez candidatos, entre os quais Hermes Lima, o vencedor, com a tese Material para um conceito de direito, de 34 páginas, e Alceu Amoroso Lima, com a tese $O$ materialismo jurídico e suas fontes, de 331 páginas (Miceli, 2001, p. 124).

É preciso assinalar que Hermes Lima, que supera Amoroso Lima em 1933 e foi nomeado à cátedra de Introdução ao Direito moderno, se inscreve numa posição teórica oposta a Amoroso Lima e próxima à perspectiva durkheimiana. Enquanto Hermes Lima se apresenta como adepto da sociologia de Durkheim e às ideias políticas de Pareto, Amoroso Lima prefere a sociologia de Le Play e de seu discípulo Tourville. Esse clima acaba concorrendo para a existência da sociologia. Segundo observa Maria Hermínia Tavares de Almeida (2001), nos anos 1930 existe certa legitimidade das Ciências Sociais no Brasil, pois nesse período os católicos, os liberais, os integristas ou os de esquerda e todas as tendências se acordam sobre o fato de que as ciências sociais deveriam indicar os caminhos das reformas políticas e sociais necessárias para o progresso do país, mesmo se entre eles houvesse desacordo sobre os tipos de ciências que deveriam conduzir ao termo as reformas sociais.

Entre os livros de Amoroso Lima do domínio da ciência social ${ }^{20}$, Preparação à sociologia é o principal, na medida em que o próprio autor o apresenta como um

20. Podemos destacar: Problemas da burguesia (1932); Introdução à economia moderna (1930); Introdução ao direito moderno (1933). 
manual de sociologia cristã $\tilde{a}^{21}$. Publicado em 1931 no Brasil, o livro recebe tradução francesa em 1934, intitulado Fragments de sociologie catholique, por uma editora conhecida, Desclée De Brouwer et Cie. A coleção “Questions Disputées” é coordenada por Charles Journet e Jacques Maritain. A tradução foi realizada por Jean Duriau e Georges Raeders, e a introdução é assinada por Jean Duriau. É importante assinalar que o livro recebe pequena notícia na Revue Néo-Scolastique de l'Université Catholique de Louvain, já mencionada ${ }^{22}$.

Como na França do final do século xIX e início do Xx, conforme vimos, no Brasil, a difusão de manuais de sociologia católica nos seminários católicos e nas escolas (de nível secundário) “era uma estratégia da elite católica para redefinir a sociologia científica nos termos dos dogmas cristãos"23 (Monteiro, 2011, p. 458). Assim, a concepção de sociologia esboçada por Amoroso Lima é de uma filosofia social fundada sobre princípios de uma sociedade cristã harmoniosa, que repulsa os conflitos e o individualismo graças à ação espiritual da Igreja. Influenciado por Le Play e pela filosofia de Maritain, o autor cede pouco espaço aos avanços das ciências sociais desenvolvidas em São Paulo por Fernando de Azevedo e Florestan Fernandes, por exemplo (Brochier, 2016, p. 29). Nesta última seção, veremos alguns elementos

21. Esse aspecto é bem indicado por Lorena Monteiro no seu texto "A cultura católica da Cátedra de sociologia nos primórdios da Universidade Federal do Rio Grande do Sul” (2011). Podemos conferir também a dissertação de mestrado, A estratégia dos católicos na conquista da sociologia, na UfrGs, Porto Alegre-Rs, 2006. Analisando os cadernos de cursos de Laudelino Teixeira de Medeiros em sociologia, no colégio Universitário (nível secundário), intelectual católico, um dos fundadores da sociologia no estado do Rio Grande do Sul, Medeiros observa que suas lições eram marcadas por uma sociologia de orientação católica. Notadamente, o conceito de Durkheim de fato social era retomado das interpretações de Alceu Amoroso Lima no livro Preparação à sociologia.

22. Pierre Harmignie, "Tristan d'Athayde, Fragments de sociologie chrétienne. Introduction par Jean Duriau". Revue Néo-Scolastique de Philosophie. 39 (50): 246-247, 1936. A introdução ressalta que Amoroso Lima era um brasileiro, jurista, tendo feito seus estudos na França, agnóstico, cristão convertido, chefe de indústria, cidadão do mundo, graças à curiosidade intelectual que o faz manter contato com uma rede de relações sociais importante, incluindo todos os movimentos de interesses literários e sociais.

23. Para maior aprofundamento, ver a tese de doutorado de Marcelo Cigales, A sociologia católica no Brasil (1920-1940):análise sobre os manuais escolares, do Programa de Pós-graduação em Sociologia Política da Universidade Federal de Santa Catarina, 2019, 313 p. Com ênfase na história do ensino de sociologia no Brasil, por meio de análise de manuais escolares católicos, o trabalho desvela as disputas de projetos educacionais e ao mesmo tempo apreende o surgimento de uma corrente sociológica, denominada católica ou cristã, concorrente da sociologia acadêmica e científica, em via de institucionalização no Brasil. As fontes remetem a oito livros e manuais escolares, escritos e traduzidos entre os anos de 1920 e 1940: Sociologia, de A. Lorton (1926); Preparação à sociologia, de Tristão de Athayde ([1931] 1942); Sociologia cristã, de Guilherme Boing, em dois volumes (1938; 1939); Noções de sociologia, de Madre Francisca Peeters ([1935] 1938); Sociologia catholica e o materialismo (Questão social), de Fernando Callage (1939); Introdução à sociologia, de Alcionilio Bruzzi Alves da Silva (1942); e Programa de sociologia, de Afro do Amaral Fontoura ([1940] 1944). 
fundamentais da sociologia católica de Alceu Amoroso Lima, confrontando principalmente a sociologia durkheimiana.

\section{Fundamentos de uma sociologia católica}

Busca-se nesta última seção apreender alguns elementos essenciais da sociologia católica de Alceu Amoroso Lima, no livro Preparação à sociologia, publicado em 1931.

O livro é composto por seis capítulos: I) Princípios sociais; II) Progresso social; III) Estrutura social; IV) Elementos sociais; v) Anomalias sociais; vi) Ordem social.

Amoroso Lima parte da constatação de que a sociologia estava no estado de precariedade, pois ela vagueia entre uma variedade de interpretações. Constantemente ela recebe da realidade histórica novas experiências. Nesse sentido, a sociologia era para ele uma ciência informe, cuja legitimidade era discutível. A situação é tal que, enquanto os sociólogos afirmam que a sociologia é uma ciência, os não sociólogos se perguntam, com ceticismo, quais são as leis que essa ciência estabeleceu e quais resultados forneceu à sociedade. Entre pessimismo e otimismo, Amoroso Lima propõe uma terceira via. Ele não crê que a sociologia seja capaz de resolver os problemas da sociedade, e avança, citando Jacques Maritain, que "não é a uma filosofia prática e sim à parte prática da teologia que de fato compete regular nossas ações" (Lima, s/d, p. 9). Essa perspectiva normativa da sociologia católica proposta por Amoroso Lima contrasta com a sociologia científica preconizada por Durkheim, que sempre defendeu uma ciência explicativa, capaz de romper com o utilitarismo, escapando de uma explicação pela causa final ou raciocínio "teleológico", que só valem para os indivíduos (Durkheim, 2014) ${ }^{24}$. Vale lembrar que, embora Durkheim critique a postura normativa da sociologia da sua época, notadamente a de Fréderic Le Play, ele afirmava desde Da divisão do trabalho social (1893) o seguinte: "Mas o fato de que nos propomos, antes de mais nada, a estudar a realidade não resulta que renunciemos a melhorá-la: estimamos que nossas pesquisas não são dignas de uma hora de trabalho, se elas só devessem ter um interesse especulativo" (Durkheim, 2004, p. XLV).

Referindo-se a Auguste Comte, Amoroso Lima afirma que sua grande obra foi tentar o monopólio da sociologia. Tais como a matemática e a biologia, ciências das relações numéricas e ciência vital, Comte pretendeu fundar a sociologia por uma poderosa sistematização científica enquanto ciência das relações sociais. Visto que a sociedade é um objeto a ser estudado, nada impede Comte de conceber a ciência da sociedade como uma ciência exata (p. 10). Para Amoroso Lima, a sociologia de seu tempo estava no mesmo estágio deixado por Comte. E desse fato, prossegue, se

24. Cf. o cap. v, "Regras relativas à explicação dos fatos sociais", pp. 91-125. 
quisermos ver construir uma ciência da sociedade, o primeiro passo a fazer é reagir, não contra a metafísica pura, mas, ao contrário, contra as metafísicas impuras, tais como os naturalistas, do mesmo modo, como a sociologia positiva se colocou contra a metafísica individualista (p. 9). Aqui, dois aspectos buscam deslegitimar a sociologia durkheimiana: primeiro, desconsideram-se os avanços da produção científica e a institucionalização da escola francesa de sociologia (identificada muito tempo como a sociologia de Durkheim), com as principais obras já publicadas - Da divisão do trabalho social (1893), As regras do método sociológico (1895), O suicídio: um estudo sociológico (1897), tido por muitos como o texto fundador da sociologia - e a revista L'Année Sociologique (1898), que reúne em torno de si colaboradores de forte e sólida formação acadêmica nas mais prestigiosas instituições de ensino na França (École Normale Supérieure e Sorbonne). O outro aspecto é que Durkheim sempre lutou contra a metafísica e se situou no campo filosófico francês do lado do racionalismo crítico encarnado por Comte e Kant, em oposição ao espiritualismo de Ravaisson e Lachelier, preferidos por Bergson, Maritain ${ }^{25}$ e o próprio Amoroso Lima.

Segundo Amoroso Lima, a ciência social deve se fundar na observação empírica dos fenômenos sociais e na interpretação filosófica desses fenômenos: "tudo o que hoje corre no mundo como sendo ciência social, veremos que não é mais do que empirismo social puro ou uma metafísica social, quase sempre naturalista" (Lima, s/d, p. 11). Para ele, é necessário reagir contra essa associação. A ciência social deve ser dividida em três partes: a sociologia (filosofia social), a sociografia (ou empirismo social) e a socioprudência (ou ação social). A ciência social é um todo, composto dessas três partes, que devem ser estudadas à luz dos princípios filosóficos morais ou dos fatos sociais, ou, ainda, em vista do progresso social. Dito de outra maneira, como a metafísica social, ou seja, a doutrina da sociedade em suas relações com os domínios do saber humano, e, portanto, como um conhecimento geral da vida. Ou enquanto observação social positiva, isto é, o conhecimento da sociedade em sua existência objetiva (histórica), preliminar em toda interpretação ou aplicação prática. E, enfim, como ação social, isso se traduz em termos concretos, em leis, em práticas de tudo o que foi observado empiricamente e para uma especulação filosófica, para construirmos verdadeiramente uma ciência social. "Quando, portanto, me refiro à sociologia como ciência social, não o faço no mesmo sentido daqueles que só julgam conhecimento certo o conhecimento 'científico'" (Idem, p. 12). Para Amoroso Lima, essa concepção positiva da ciência confunde terrivelmente as coisas. Ele propõe considerar as coisas à luz de uma concepção integral da realidade, a saber, que não

25. Isaac Benrubi, Les sources et les courants de la philosophie contemporaine en France, 2 vols. Paris, Alcan, 1933. 
se limita ao conhecimento no domínio das realidades sensíveis, que fez o mundo moderno, a partir de Kant, perder a fé na inteligência (p. 12).

Amoroso Lima distingue duas concepções da vida: uma cristã e uma concepção agnóstica ou materialista. O que as diferencia é o totalismo, a incorporação completa da realidade. Para o autor, nós estamos diante de dois sistemas filosóficos no que concerne à ciência e à realidade. Uma concepção que reduz o conhecimento da realidade aos fatos, às leis, na qual o homem é a medida de todas as coisas; e uma concepção que leva em conta a variedade concreta de todas as riquezas e a complexidade dos indivíduos, adaptando o conhecimento de cada um à sua realidade específica. $\mathrm{Na}$ primeira concepção encontramos a subjetividade de Kant e de todos os neokantianos, sobretudo dos positivistas e dos materialistas; na segunda, encontramos o objetivismo aristotélico-tomista, greco-medieval (pp. 12-13). É nessa última concepção que Amoroso Lima entende fundar sua concepção da sociologia, que ele define como uma sociologia finalista ou integral. Essa última pretende restabelecer o equilíbrio perdido entre a sociedade e o indivíduo. Ela não vem confirmar a natureza, ou ainda menos negar a ação das causas segundas. Ela quer demonstrar simplesmente que a natureza é insuficiente para explicar a si mesma (p. 16).

Do que foi dito, é evidente a oposição que Amoroso Lima faz ao campo filosófico de tradição kantiana e neokantiana, ao positivismo e às ciências sociais da natureza (p. 15). Ele reprova essas tradições de reduzir o homem ao nada: em si, o homem não é nada, para a sociologia naturalista, derivada de Comte e Durkheim, que encontraram muitos adeptos. Para essa sociologia o homem é simplesmente um ponto de passagem. A existência real é a sociedade. Como Simon Deploige outrora, Amoroso Lima critica a sociologia de tradição durkheimiana de ter "deificado a sociedade e de dissolver o homem na sua individualidade, no processo social". Ele remete essa concepção a Comte que, segundo entende, não concebia a psicologia como uma ciência autônoma, porque o homem não tinha uma existência em si. Por consequência, o homem se torna o objeto de toda ciência; a biologia estuda o que de animal existe nele; a sociologia, o social. A oposição mais clara estabelecida entre a sociologia católica preconizada por Amoroso Lima e a sociologia durkheimiana se dá na distinção que o autor brasileiro faz entre o que ele chama de sociologia naturalista ou determinista (oriunda da Comte e mais especificamente de Durkheim) e a sociologia que ele pretende fundar a partir dos postulados filosóficos aristotélicos-tomistas e teológicos. Àquela sociologia naturalista e determinista ele opõe uma sociologia social cristã, segundo ele "a forma mais completa da sociologia finalista" (p. 37).

Essa perspectiva leva a uma concepção distinta do fato social. Para Amoroso Lima, a formação da estrutura social é composta da seguinte forma: a) a vida natural, a vida; b) a vida individual, o homem; c) a vida familiar, a família; d) a vida econômica, o 
grupo profissional; e) a vida cívica, o Estado; f) a vida internacional, a Sociedade das Nações; e a vida sobrenatural, a Igreja. Esses elementos se desenvolveriam de maneira harmoniosa e integral formando a sociedade cristã. Reduzidos como um triângulo, esses elementos básicos seriam: a natureza, o homem e a sociedade, que, por conseguinte, formam os elementos básicos do fato social, como deve compreender a sociologia finalista (p. 90). Nisso sua sociologia cristã se opõe diretamente à sociologia durkheimiana, classificada na sua obra como naturalista.

A concepção naturalista dá ao fato social um significado excessivamente objetivo, suprimindo-lhe todo o caráter humano, para atribuir-lhe apenas uma tipologia estatística, confundindo o fato físico ou biológico, objeto das ciências experimentais. Se o estudo da sociedade, antes de Comte e Le Play, não possuía do fato social senão uma concepção muito larga demais, podemos dizer que a concepção naturalista do fato social lhe deu um âmbito excessivamente estreito (Lima, s/d, p. 90).

É importante lembrar que a contestação da definição do fato social dada por Durkheim é corrente na sua época. Notadamente seu postulado de que os fatos sociais devem ser tratados como coisas repercutiu muito no meio católico ${ }^{26}$. No que concerne ao estreitamento, segundo Amoroso Lima, que a sociologia naturalista teria feito do fato social - leia sociologia durkheiminana -, a circunscrição do objeto da sociologia, em As regras do método, ganha outra explicação:

\footnotetext{
Eis, portanto, uma ordem dos fatos que apresentam características muito especiais: consistem em maneiras de agir, de pensar e de sentir, exteriores ao indivíduo, e que são dotadas de um poder de coerção em virtude do qual esses fatos se impõem a ele. Por conseguinte, eles não poderiam se confundir com os fenômenos orgânicos, já que consistem em representações e em ações; nem com os fenômenos psíquicos, os quais só têm existência na consciência individual e através dela. Esses fatos constituem, portanto, uma espécie nova, e é a eles que deve ser dada e reservada a qualificação de sociais (Durkheim, 2014, pp. 3-4).
}

Vê-se, portanto, que o esforço de Durkheim é para constituir a autonomia e especificidade da natureza dos fatos sociais, vis-á-vis da biologia e da psicologia, necessário para tornar a sociologia uma disciplina autônoma no campo científico, contrariamente ao que afirma Amoroso Lima na passagem anterior.

26. Veja, a esse respeito, o prefácio à segunda edição de As regras do método sociológico (Durkheim, 2014, pp. XV-XXXI). 


\section{Considerações finais}

Este artigo buscou objetivar as estratégias da Instituição católica para se opor à sociologia universitária, fundada sob a égide de Émile Durkheim, na França, que no Brasil teve notáveis representantes como Fernando de Azevedo e Florestan Fernandes, homens de frente no processo de institucionalização da sociologia como ciência e do seu ensino no Brasil. Ora, o projeto de fundar uma sociologia católica para rivalizar com a sociologia durkheimiana, como na França, se dá num contexto de reaparelhamento da Igreja Católica, da refundação da filosofia de Santo Tomás de Aquino e da formação do catolicismo social. Para tanto, a Instituição católica instala um conjunto de dispositivos institucionais: recrutamento de intelectuais católicos de tradição neotomista, criação de institutos de ensino superior, revistas filosóficas de vocação neoescolástica, que serviram de veículos de difusão do neotomismo e do pensamento social católico.

A partir da investigação que temos realizado sobre essa temática nos dois países, postula-se que existem características assaz comuns, a saber: a) Como afirma Serry: "A sociologia católica empírica, inspirada pelos textos doutrinais oficiais, não se insere nos debates sobre o status e as condições epistemológicas de uma ciência do social" (2004b, p. 32). Os autores da sociologia católica não citam senão marginalmente os sociólogos reconhecidos da época como Durkheim, Tarde, Fouillée. E quando o fazem, é para insistir sobre as insuficiências da "sociologia científica". b) As produções de manuais de sociologia católica são investimentos feitos por personalidades em grande parte do corpo eclesiástico, muitos sem uma grande formação universitária, sendo assim mais caracterizados como autodidatas. Desse modo, ficaram à margem dos espaços mais acadêmicos e universitários. c) Os fundamentos teóricos são orientados pelo neotomismo e pelo ensino social da Igreja, caracterizando-se como uma sociologia normativa e apologética ${ }^{27}$. d) O alvo principal foi a sociologia de Durkheim, apesar de as críticas ao positivismo comtiano e ao marxismo estarem explicitamente presentes desde a Rerum Novarum.

Nos dois casos, Brasil e a França, a Instituição católica busca recuperar um espaço social de notoriedade, relegado após a expansão de uma sociedade democrática e republicana no contexto do desenvolvimento econômico e industrial, no qual a sociologia acadêmica tem forte penetração no ensino superior e secundário, contribuindo para a formação do espírito crítico e cidadão.

27. Cf. a introdução ao dossiê Sociologies Catholiques, Archives de Sciences Sociales des Religions, 179: $17-$ 24, (Chatelan, 2017). 
Referências bibliográficas

Abreu, A. et al. ([1984] 2001), Dicionário histórico-biográfico brasileiro, pós-1930. Rio de Janeiro, Florense Universitária/Finep.

Almeida, M. H. T. ([1989] 2001), "Dilemas da institucionalização das ciências sociais no Rio de Janeiro". In: MiCELI, S. (org.). História das ciências sociais no Brasil. 2 ed. rev. e corr. São Paulo, Editora Vértice.

Audren, F. (1 ${ }^{\circ}$ semestre 2005a), "Découvrir Paul Bureau et la science sociale”. Études Sociales - Paul Bureau et les Sciences Sociales, n. 141: 3-8.

Audren, F. ( $1^{\circ}$ semestre 2005b), "Sociologie, action sociale et morale catholique chez Paul Bureau". Études Sociales - Paul Bureau et les Sciences Sociales, 141: 9-88.

Belliot, A. (1911), Manuel de sociologie catholique : histoire, théorie, pratique. Paris, P. Lethielleux, Librairie-Éditeur.

BenRUbi, I. (1933), Les sources et les courants de la philosophie contemporaine en France, 2 vols. Paris, Alcan.

Brochier, C. (2016), La naissance de la sociologie au Brésil. Rennes, PUR.

Bureau, P. (1923), La science des mours. Introduction à la méthode sociologique. Paris, Bloud et Gay.

Campos, F. A. (1998), Tomismo no Brasil. São Paulo: Paulus.

Chatelan, O. (Juillet-septembre 2017), “Introduction”. Archives de Sciences Sociales des Religions: Sociologies catholiques. La circulation des référents islamiques. En ligne, 179: 1724. Mis en ligne le 01 septembre 2017, URL: http://journals.openedition.org/assr/29564, consultado em 01/06/2018.

Cigales, Marcelo. (2019), A Sociologia Católica no Brasil (1920-1940): análise sobre os manuais escolares, 313 p. Santa Catarina, tese de doutorado, Programa de Pós-Graduação em Sociologia Política da Universidade Federal de Santa Catarina.

Cuchet, G. (juillet-septembre 2012), "La réception catholique des Formes élémentaires de la vie religieuse (1912) d'Émile Durkheim”. Archives de Sciences Sociales des Religion, 159: 29-49.

Deploige, S. (1927), Le conflit de la morale et de la sociologie. Paris, Nouvelle Librairie Nationale.

Daros, M. das Dores \& Pereira, E. A. T. (jan./abr. 2015), Rev. Bras. Hist. Educ., Maringá-PR, 15, 1 (37): 235-267.

Durkheim, E. (1913), "Reviewed work: Manuel de sociologie catholique by R. P. A. Belliot”. L'Année Sociologique (1909-1912), 12: 14.

Durkheim, E. ([1895] 2014), As regras do método sociológico. São Paulo, Martins Fontes.

Durkheim, E. (2004), Da divisão do trabalho social. São Paulo, Martins Fontes.

Fournier M. (2007), Émile Durkheim (1858-1917). Paris, Fayard.

Harmignie, Pierre. (1936), “Tristan d'Athayde, Fragments de sociologie chrétienne. Introduction par Jean Duriau”. Revue Néo-scolastique de Philosophie. 39 (50): 246-247. 
Henry, O. \& Serry, H. (juin 2004), "La sociologie, enjeux de luttes”. Actes de la Recherche en Sciences Sociales, 153.

Lima, A. A. (1973), Memórias improvisadas. Petrópolis, Vozes.

Lima, A. A. (s/d), Preparação à sociologia. Rio de Janeiro, Schmidt Editor.

Lima, A. A. (1934), Fragments de sociologie catholique. Paris, Desclée de Brouwer et Cie. “Questions Disputées”.

LEÃo XIII. (1999), Encyclique Aeterni Patris (1879). La philosophie Chrétienne. Paris, Pierre Téqui Editeur.

LEÃO XIII. ([1891] 1965), Rerum Novarum. São Paulo, Paulinas.

Maritain, J. (1923), "Préface à la troisième édition". In: Deploige, S. (1927), Le conflit de la morale et de la sociologie. Paris, Nouvelle Librairie Nationale, pp. XVII-XX.

Maritain, J. (1983), “Saint Jean de la Croix, praticien de la contemplation”. OEuvres complètes, vol. Iv.

Mercier, D.-J. (1894), “Introduction”. Revue Néo-Scolastique, n. 1.

Meucci, S. (2011), Institucionalização da sociologia no Brasil: primeiros manuais e cursos. São Paulo, Hucitec, Fapesp.

Miceli, S. (1981), Les intellectuels et le pouvoir au Brésil (1920-1945). Paris, Presses Universitaires de Grenoble, PUG/Maison des Sciences de l'Homme.

Miceli, S. (2001), Intelectuais à brasileira. São Paulo, Companhia das Letras.

Monteiro, L. M. (abr.-jun. 2011), “A cultura escolar católica da cátedra de sociologia nos primórdios da Universidade Federal do Rio Grande do Sul". Educação e Sociedade, Campinas, 32 (115): 453-469. Disponível em http://www.cedes.unicamp.br.

Naudet, P. (1899), Premiers principes de sociologie catholique. Paris, Librairie Bloud et Barral.

Lorton, A. (1923), Notions de sociologie. Paris, Gigord.

Oliveira, M. (2009), "Émile Durkheim e a sociologia brasileira”. In: Massella, Alexandre B. (org.). Durkheim: 150 anos. Belo Horizonte, Argvmentvm, pp. 231-257.

Padilha, T. \& Velez, R. (1998), "La philosophie au Brésil”. In: Encyclopédie philosophique universelle: Iv. Le Discours Philosophique. Paris, PUF.

Plouviez, M. (2005), "De la Science positive de la morale à la morale sociologique - Paul Bureau, lecteur de Durkheim”. Les Études Sociales, Société d’Économie et de Sciences Sociales, Paul Bureau (1865-1923) et la Science Sociale, 141: 89-120.

Poey, P. (1914), Manuel de sociologie d’après les documents pontificaux, à l'usage des Séminaires et des Cercles d'études. Paris, Gabriel Beauchesne Éditeur.

Serry, H. (2004a), Naissance de l'intellectuel catholique. Paris, La Découverte.

Serry, H. (2004b), "Saint Thomas sociologue? Les enjeux cléricaux d'une sociologie catholique dans les années 1880-1920”. Actes de la Recherche en Sciences Sociales, 3 (153): 28-40.

Velloso, M. P. “A Ordem: uma revista de doutrina, política e cultura católica”. Revista de Ciência Política, Rio de Janeiro, 21 (3), 1978: 117-160. 


\section{Resumo}

A sociologia católica de Alceu Amoroso Lima contra a sociologia durkheimiana no Brasil

A fundação da sociologia por Durkheim assiste na França ao retorno da filosofia tomista, resultado de uma "estranha aliança" entre a Igreja católica e os intelectuais. Buscando impedir o avanço das ciências sociais, em especial da sociologia durkheimiana, e estabelecer o catolicismo social, a "sociologia católica" encontra seus fundamentos no tomismo e no ensino social de Leão XIII. Após situar a tensão entre sociologia católica e sociologia durkheimiana na França, o artigo objetiva analisar os mecanismos de difusão do neotomismo francês no Brasil, e suas influências na formação de uma sociologia católica brasileira; identificar os agentes sociais e os órgãos que contribuíram com a profissionalização do ensino da sociologia. De cunho histórico e bibliográfico, ele se inscreve numa sociologia dos intelectuais, consagrando um lugar especial a Alceu Amoroso Lima, figura central no corpus da tradição intelectual católica brasileira. A pesquisa conclui que Amoroso Lima se alinha aos católicos sociais franceses por sua origem social, sua trajetória no espaço acadêmico, que combina fracassos universitários e reconversão do capital social e simbólico; e sua inscrição no campo filosófico ligado ao espiritualismo bergsoniano no início e, mais tarde, ao neotomismo de Maritain. Tais prerrogativas lhe dão direito de entrar no campo das ciências sociais rivalizando com a sociologia acadêmica em via de institucionalização. Palavras-chave: Sociologia católica; Sociologia Durkheimiana; Fato social; Neotomismo.

\section{Abstract}

Alceu Amoroso's catholic sociology opposed to Durkheim's sociology in Brazil

Émile Durkheim's sociology founding watches the comeback of the Thomistic philosophy in France, resulting from an "awkward alliance" between the Catholic church and the intellectuals. This project intended to thwart the spread of social sciences, especially Durkheim's sociology, and stablish the catholic sociology, in order to allow the Catholic church to recover its prestigiousness in the modern society. The "catholic sociology" is substantiated by the Thomistic philosophy and Leo XIII's social teaching. After pointing out the conflict between the catholic sociology and Durkheim's sociology in France, the article aims to analyze the mechanisms that spread the French neo-Thomism in Brazil and its influences on the founding of the Brazilian catholic sociology, afterwards, it is intended to identify the social agents and the institutions that contributed to the professionalization of the sociology's teaching. Historically and bibliographically, the article is located on an intellectual's sociology, reserving a special place to Alceu Amoroso Lima, main author in the corpus of the Brazilian intellectual catholic tradition. The research shows that Amoroso Lima is aligned to the French social Catholics for his social origin, his academic path, which combines university failures and reconversion of the social and symbolic capitals; his position on the philosophic field, linked to Bergson's spiritualism in the beginning, and to Jacques Maritain's neo-Thomism later, are prerogatives that give him 
the right to enter on the social science being opposite to the academic sociology through the institutionalization.

Keywords: Catholic sociology; Durkheim's sociology; Social fact; Neo-Thomism.

Texto recebido em 16/04/2020 e aprovado em 01/06/2021.

DOI: 10.11606/0103-2070.ts.2021.168845

Juarez Lopes de Carvalho Filho é doutor em Sciences Sociales et Économiques, pelo Institut Catholique de Paris (França). É professor Associado do Departamento de Sociologia e Antropologia e membro do corpo docente do Programa de Pós-graduação em Ciências Sociais na Universidade Federal do Maranhão (São Luís, Brasil). E-mail: juarez.lopes@gmail.com. 